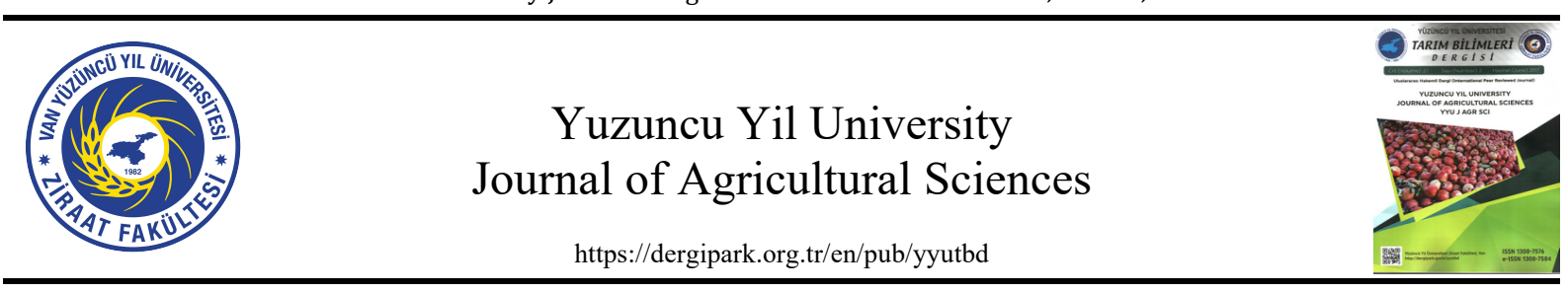

Research Article

\title{
Identification and Antimicrobial Activity of Actinobacteria Isolated from Rhizosphere of the Local Endemic Plants
}

\author{
Süleyman ÖZAKIN ${ }^{1,3}$, Bilgin TAŞKIN ${ }^{2}$, Ebru İNCE BOSTANCI ${ }^{* 3}$ \\ ${ }^{1}$ Current address: Biem Pharmaceutical Research \& Development Department Martek-Tübitak, İzmit, Turkey \\ ${ }^{2}$ Van Yuzuncu Yil University, Faculty of Agriculture, Department of Agricultural Biotechnology, 65080, Van, \\ Turkey \\ ${ }^{3}$ Dicle University, Faculty of Science, Department of Biology, 21280, Diyarbakır, Turkey \\ ${ }^{1} \mathrm{https} / / /$ orcid.org/0000-0001-9536-9852 ${ }^{2} \mathrm{https} / /$ orcid.org/0000-0002-9772-7438 ${ }^{3} \mathrm{https}: / /$ orcid.org/0000-0002-9048-5798 \\ *Corresponding author e-mail: eince@dicle.edu.tr
}

\section{Article Info}

Received: 26.06 .2021

Accepted: 22.11 .2021

Online Published:15.12.2021

DOI: $10.29133 /$ yyutbd.957756

Keywords

16S rRNA,

Actinobacteria,

Antimicrobial activity,

Molecular identification,

Secondary metabolites.

\begin{abstract}
The search for novel antimicrobial compounds from the environment has been gaining momentum with the increase in resistance of pathogens. In the present study, the antimicrobial potential of 11 local isolates of Actinobacteria which were isolated from rhizosphere soils of the three local endemic plants in Turkey was evaluated against different pathogenic bacteria and Candida albicans. Antimicrobial activity was investigated by the disk diffusion agar method using the organic extracts obtained from the isolates grown in the modified Bennett's medium and Tryptic Soy Broth (TSB). Eight isolates were revealed to show remarkable antimicrobial activity against to pathogens. Study of the production of bioactive metabolites in two different culture media indicated that the higher antimicrobial activity was observed in modified Bennett's medium when compared to TSB. Also, partial 16S rDNA sequence analyses revealed that 10 of these local isolates belong to member of Streptomyces and one of them to member Promicromonospora genera.
\end{abstract}

\section{Lokal Endemik Bitki Rizosferinden İzole Edilen Aktinobakterilerin Tanımlanması ve Antimikrobiyal Aktivitesi}

\section{Makale Bilgileri}

Geliș: 26.06.2021

Kabul: 22.11 .2021

Online Yayınlanma: 15.12.2021

DOI: $10.29133 /$ yyutbd.957756

\section{Anahtar kelimeler}

16S rRNA,

Aktinobakteriler, Antimikrobiyal aktivite, Moleküler tanımlama, İkincil metabolitler.

\begin{abstract}
Öz: Patojenlerin direncinin artmasıyla birlikte yeni antimikrobiyal bileşik arayış1 hız kazanmaktadır. Bu çalışmada, Türkiye'deki üç yerel endemik bitkinin rizosfer topraklarından izole edilen 11 lokal Aktinobakteri izolatının farklı patojen bakterilere ve Candida albicans'a karşı antimikrobiyal potansiyeli değerlendirilmiştir. In vitro antimikrobiyal aktivite, modifiye Bennett's ve Tryptic Soy Broth (TSB) besiyerinde üretilen izolatların organik özütleri kullanılarak disk difüzyon agar yöntemiyle araştırılmıştır. Sekiz izolatın patojenlere karşı kayda değer antimikrobiyal aktiviteye sahip olduğu belirlenmiştir. Biyoaktif metabolitlerin üretimi üzerine iki farklı kültür ortamının incelenmesi sonucu, modifiye Bennett ortamında daha yüksek antimikrobiyal aktivitenin elde edildiği bulunmuştur. Ayrıca kısmi 16S rDNA dizi analizleri ile bu lokal suşların 10'unun Streptomyces ve birinin de Promicromonospora cinsine ait olduğu tespit edilmiştir.
\end{abstract}




\section{Introduction}

The phylum Actinobacteria are considered to be one of the top producers of secondary metabolites, such as antibiotics, immunosuppressors, antifungals and antitumoral, etc. (Ay, 2020; Kämpfer and Labeda, 2006). The Streptomyces, which is the largest genus of Actinobacteria, consists of almost 800 species with published names (www.bacterio.net/streptomyces.html). In recent years, as a result of the new generation sequencing analyses into the Actinobacterial systematics, many reclassifications have been made within the genus Streptomyces (Nouioui et al., 2018). However, $16 \mathrm{~S}$ rRNA sequence data still are valuable in the systematics of this genus (Fguira et al., 2005).

One of the important features of the Streptomyces genome is the presence of gene clusters responsible for the synthesis of crucial secondary metabolites (Nett et al., 2009). Streptomyces genus has been an important reservoir of medically important metabolites, particularly antibiotics. Since the first antibiotic discovery, many antibiotics have been isolated and described from various Streptomyces species (Berdy, 2005). The great importance of Streptomyces species is due to the urgent need to discover new antimicrobial compounds because of the rapid increase of multi-drug-resistant microbial pathogens (Bush et al., 2011). For this reason, Streptomyces has become the main focus of isolation and investigation from different habitats including plant root environment (Yilmaz et al., 2008). Moreover, the large amount of information gathered about Streptomyces species makes them more amenable to the application of -omic techniques to unlock their potential to produce potent bioactive metabolites (Nett et al., 2009). Therefore, systematic investigation of Streptomyces species becomes more important as they still have the potential to produce many undiscovered secondary metabolites.

This study aimed to determine the variety of Actinobacteria isolated from the rhizosphere soils of three endemic plants, Aethionema dumanii, Salvia aytachii, and Achillea ketenoglui from Beypazarı, Turkey, by $16 \mathrm{~S}$ rRNA reading. Also, in vitro investigation of antimicrobial activities of isolates grown in two different test media by the disk diffusion agar method is another achievement of this study.

\section{Material and Methods}

\subsection{Actinobacterial isolates and test organisms}

Bacteria were previously isolated from the alkaline root surrounding soil of A.dumanii, S.aytachii, and A. ketenoglui endemic plants near Ayaş-Beypazarı (Ankara), Turkey (Yilmaz et al., 2008).

In the study of evaluation of antimicrobial properties of the ethyl acetate extracts obtained from the isolates grown in the modified Bennett's and Tryptic Soy Broth (TSB) media, Escherichia coli (ATCC 25922), Staphylococcus aureus (ATCC 25923), Streptococcus pyogenes (ATCC 19615), Pseudomonas aeruginosa (ATCC 27853) and Candida albicans (ATCC 10231) were used as the indicator microorganisms for antimicrobial activity assay. All strain cultures were grown either in Nutrient Broth (NB) broth (Difco, Detroit, MI, USA) or on Nutrient Broth agar plates at $25{ }^{\circ} \mathrm{C}$. Sabouraud Dextrose Agar (SDA, Merck) or broth was used for C. albicans production.

\subsection{Genomic DNA isolation and PCR}

TSB medium with $0.5 \%$ maltose was used to grow the isolates using an orbital shaker (230 rpm) for 48 hours. $2 \mathrm{ml}$ of it was transferred to a liquid medium containing TSB-YEME and left to incubate at $28{ }^{\circ} \mathrm{C}$ for 24 hours in the orbital shaker $(230 \mathrm{rpm}) .1 .5 \mathrm{ml}$ culture was centrifuged and washed twice using $10.3 \%$ (w/v) sucrose solution. Pellet was dissolved in $500 \mu 1 \mathrm{TSE}$ buffer $\left(25 \mathrm{mmol}^{-1}\right.$ Tris- $\mathrm{HCl}$ pH 8.0, $300 \mathrm{mmol} \mathrm{l}^{-1}$ sucrose, $25 \mathrm{mmol} \mathrm{l}^{-1}$ EDTA) supplemented with $2 \mathrm{mg} \mathrm{ml}^{-1}$ lysozyme and $50 \mu \mathrm{g} \mathrm{ml} l^{-}$ ${ }^{1}$ RNase and incubated at $37{ }^{\circ} \mathrm{C}$ for $30 \mathrm{~min} .300 \mu 12 \%$ (w/v) SDS was added and vortexed for $20 \mathrm{~s}$. Phenol:chloroform:isoamyl alcohol $(25: 24: 1, \mathrm{v} / \mathrm{v} / \mathrm{v})$ solution was used for extraction, and it was followed by another extraction step with an equal volume of chloroform:isoamyl alcohol $(24: 1, \mathrm{v} / \mathrm{v})$. In the last step, the DNA in the supernatant was precipitated by standard precipitation method using sodium acetate $(3 \mathrm{M})$. 


\subsection{Genotypic characterization of the isolates}

The isolates were identified by partial 16S rRNA gene sequencing. The genes were amplified in a polymerase chain reaction (PCR) using the chromosomal DNA as a template and universal bacterial primers, 8f (5'-AGAGTTTGATCCTGGCTCAG-3') and 1492r (5'- GTTACCTTGTTACGACTT-3'). A $50 \mu \mathrm{l}$ reaction mixture contained $2.5 \mathrm{U}$ Taq polymerase (Thermo Fisher Scientific, Waltham, MA, USA), $0.3 \mathrm{mM}$ dNTPs, $25 \mathrm{mM} \mathrm{MgCl}_{2}, 20$ pmol of each primer, $5 \mu 1$ of $10 \mathrm{x}$ reaction buffer (Thermo Fisher Scientific), and $100 \mathrm{ng}$ of template DNA. The step-up PCR procedure included denaturation at $95^{\circ} \mathrm{C}$ for $5 \mathrm{~min}$, followed by 30 cycles of $94^{\circ} \mathrm{C}$ for $1 \mathrm{~min}, 55^{\circ} \mathrm{C}$ for $1 \mathrm{~min}$, and $72^{\circ} \mathrm{C}$ for $2 \mathrm{~min}$, with a final extension at $72^{\circ} \mathrm{C}$ for $10 \mathrm{~min}$. Amplification products were run on a $1 \%$ agarose gel. DNA of the expected size was purified from the gel with the QIAquick gel extraction kit (Qiagen, Hilden, Germany).

16S rRNA gene regions were performed by Iontek Biotechnology Company (Turkey) using the chain termination method with Thermo Sequenase II Dye Terminator Cycle Sequencing Kit (Amersham), using a Perkin Elmer-ABI Prism 377 automated sequencing platform. The sequences obtained were analyzed using the database on the website "https:/www.ezbiocloud.net/", and then the sequences were logged in to the GenBank site and accessed accession numbers. The phylogenetic tree was constructed by the GGDC web server at http://ggdc.dsmz.de/ using the phylogenomic data line DSMZ (German Collection of Microorganisms and Cell Cultures $\mathrm{GmbH}$ ) adapted to single genes (Meier-Kolthoff et al., 2013). Multiple sequence alignment was done with "MUSCLE" (Edgar, 2004), and the phylogenetic tree was created using the Maximum Likelihood method (Stamatakis, 2014).

\subsection{Extraction of crude metabolites}

Each of 11 isolates was inoculated aseptically into $50 \mathrm{ml}$ Bennett's medium in baffled flasks (1 $\mathrm{g}$ yeast extract (Fluka), $1 \mathrm{~g}$ beef extract (Acumedia), $2 \mathrm{~g}$ bacto casein (Difco), and $10 \mathrm{~g}$ glucose per 1 in tap water, $\mathrm{pH} 7.8$ ) or TSB (Oxoid) media. They were incubated for $3-5$ days at $28^{\circ} \mathrm{C}$ in a rotary shaker at $250 \mathrm{rpm}$. Then, $500 \mu \mathrm{l}$ of liquid cultures were inoculated in $50 \mathrm{ml}$ media again and then left for incubation for three days.

After three days of incubation, a press was used to separate the mycelium and supernatant of the culture. The supernatant was extracted with ethyl acetate (EtOAc) $(2 \times 100 \mathrm{ml})$. Both extracts were combined and dried with $\mathrm{Na}_{2} \mathrm{SO}_{4}$. Crude extracts were obtained by evaporation to dryness under reduced pressure and weighed. Then they were dissolved in ethyl acetate (EtOAc) and used for antimicrobial screening.

\subsection{In vitro antibacterial activity}

The antibacterial activity of the extracts was evaluated using the disk diffusion method (NCCLS, 2002). Bacterial and C. albicans suspensions were prepared with the spectrophotometric method. The final bacterial and C. albicans concentration applied on the agar surface was approximated to $10^{7} \mathrm{CFU}$ and $10^{4}$, respectively. The disk diffusion method was performed using Nutrient Agar (NA, Oxoid) for bacteria and Sabouraud Dextrose Agar (SDA, Oxoid) for C. albicans. Sterile test discs (Bioanalyse Co., Ltd., Ankara, Turkey) were placed on the agar surface, which had been previously inoculated with 0.1 $\mathrm{mL}$ bacterial suspension at an equal distance from each other. $20 \mu \mathrm{L}$ of each extract was directly applied onto the disks, and the plates were left for incubation at $37^{\circ} \mathrm{C}$. Inhibition zones were measured after 24 hours for bacteria and 48 hours for C. albicans. Antibiotic discs (all from Oxoid) containing imipenem $\left(10 \mu \mathrm{g}\right.$ disc $\left.{ }^{-1}\right)$, ofloxacin $\left(5 \mu \mathrm{g} \mathrm{disc} c^{-1}\right)$, netilmicin $\left(30 \mu \mathrm{g} \mathrm{disc}^{-1}\right)$, amoxicillin $\left(30 \mu \mathrm{g} \mathrm{disc}^{-1}\right)$, erythromycin $\left(15 \mu \mathrm{g} \mathrm{disc}^{-1}\right)$, and Amphotericin B $\left(20 \mu \mathrm{g} \mathrm{disc}^{-1}\right)$ were used to test the antibiotic susceptibility. EtOAc was used as a negative control for each experiment in the disk diffusion method. The presence of a clear zone around the disks was considered as inhibition.

\section{Result and Discussion}

The rapid spread of antibiotic resistance among pathogens has created an urgent need for drugs. Bioactivity-guided screening of the novel secondary metabolites from microorganisms may provide the potential to overcome the antimicrobial drug-resistance, which is a great public health problem (WHO, 
2014; Schein, 2020). In the present study, it was aimed to screen the rhizospheric Actinobacteria to determine the effective anti-microbial strains against pathogen organisms.

Partial (300-600 bp) 16S rRNA gene sequencing of isolates yielded 10 Streptomyces and 1 Promicromonospora genera according to homology search using the EZBioCloud database (Table 1). The full-length 16S rRNA gene contains nine variable regions (V1-V9) distributed throughout the highly conserved sequence. Our partial sequences (300-600 bp) cover the V1-V3 variable regions (Johnson et al., 2019). Since modern analysis sequencing methods provide an appropriate read of full-length of the $16 \mathrm{~S}$ rRNA gene, they have the potential to give a better taxonomic analysis of bacterial communities at genus, species, and even strain levels. However, it was also shown that although the full V1-V9 region consistently produced the best results, some sub-regions sequencing produced very good results for classifying sequences for some genera. For example, the V1-V3 region gave satisfactory results for Escherichia/Shigella (Johnson et al., 2019). Taxonomic analysis based on the initial 120-bp sequences has been demonstrated in some previous studies to be useful for the identification of Streptomyces species (Kataoka et al., 1997). Also, Yilmaz et al., (2008) constructed phylogenetic trees by the neighbor-joining method in their study using both full length and partial 16S rRNA sequences of Streptomyces isolates and representative strains. They found that the general topologies of trees from both sequences were similar. On the other hand, genetic distance was more pronounced in the partialsequence tree.

Table 1. Identification of isolates and GenBank accession numbers according to the results of sequence analysis using the EzBioCloud database

\begin{tabular}{|c|c|c|c|c|c|}
\hline $\begin{array}{c}\text { Code of } \\
\text { the } \\
\text { Isolates }\end{array}$ & Top-hit Taxon & $\begin{array}{l}\text { Top-hit } \\
\text { Strain }\end{array}$ & $\begin{array}{l}\text { Similarity } \\
(\%)\end{array}$ & Completeness (\%) & $\begin{array}{c}\text { GenBank } \\
\text { Accession } \\
\text { Numbers }\end{array}$ \\
\hline AR9 & $\begin{array}{c}\text { Promicromonospora } \\
\text { xylanilytica }\end{array}$ & YIM 61515 & 99.50 & 27.7 & MT741827 \\
\hline CS41 & Streptomyces chryseus & $\begin{array}{l}\text { NRRL B- } \\
12347\end{array}$ & 99.03 & 21.4 & EF494233 \\
\hline CA12 & $\begin{array}{c}\text { Streptomyces } \\
\text { spiroverticillatus }\end{array}$ & NBRC 12821 & 98.33 & 20.7 & MT738695 \\
\hline BS32 & $\begin{array}{l}\text { Streptomyces } \\
\text { seymenliensis }\end{array}$ & B1041 & 98.63 & 35.2 & MT733233 \\
\hline BS29 & Streptomyces hypolithicus & HSM10 & 99.71 & 23.3 & MT733215 \\
\hline BA14 & Streptomyces peucetius & JCM 9920 & 98.78 & 22.6 & MT733216 \\
\hline BA12 & Streptomyces xiangluensis & NEAU-LA29 & 99.03 & 21.3 & MT733214 \\
\hline AS36 & Streptomyces narbonensis & NBRC 12801 & 99.67 & 41.7 & MT733200 \\
\hline AS28 & Streptomyces chryseus & $\begin{array}{l}\text { NRRL B- } \\
12347\end{array}$ & 99.73 & 25.7 & MT733199 \\
\hline AR6 & Streptomyces flavofungini & NBRC 13371 & 99.49 & 41.0 & MT733185 \\
\hline AR4 & $\begin{array}{l}\text { Streptomyces } \\
\text { shaanxiensis }\end{array}$ & $\begin{array}{c}\text { CCNWHQ } \\
0031\end{array}$ & 99.36 & 21.6 & MT733183 \\
\hline
\end{tabular}

The 16S rRNA gene sequencing results of all our isolates revealed $98-99.73 \%$ similarity rates (Table 1). Stackebrandt and Goebel, (1994) proposed the 97\% 16S rRNA sequence similarity threshold to confirm that the two strains do not belong to the same species. Then, $98.7 \%$ sequence similarity ratio was suggested as an originality value, which is higher than the $97 \%$ threshold value (Stackebrandt and Ebers, 2006). After a few years, it was proposed that a $98.65 \%$ similarity ratio can be used as the threshold of distinguishing two species (Kim et al., 2014). Except for isolate BS32, the 16S rRNA gene sequencing results of all our isolates yielded a higher than $98.65 \%$ similarity rate. The similarity value of the isolate BS32 $(98.63 \%)$ which was related to Streptomyces seymenliensis is very close to this threshold (Figure 1). Therefore, it can be stated that our partial 16S rRNA sequences did not yield a new species. It should be noted, however, that although the 16S rRNA gene sequence is a strong indicator, it may not be sufficient alone to identify a new species. A polyphasic approach that encompasses phenotypic and chemical characterizations as well as whole genome-based analysis should be adopted to precisely determine the taxonomic position of a strain (Tindall et al., 2010). 
Antimicrobial activities of 11 identified isolates that were grown in modified Bennett's medium and TSB are shown in Table 2. Table 3 shows the results of the antibacterial test of some of the standard antibiotics against tested microorganisms. It was shown that the crude EtOAc extracts of 8 of the isolates had antimicrobial activity against different test organisms. Among them, extracts of CS41 isolate grown in modified Bennett's medium were found to have a strong inhibitory effect on Gram-positive organisms. BS29 grown in the same medium was the only isolate showing both antibacterial and antifungal activity. No antimicrobial effect of the majority of the extracts from isolates grown in TSB medium was observed against test microorganisms. On the other hand, EtOAc extracts of isolates grown in modified Bennett's medium showed remarkable antimicrobial activity (Table 2). According to the results, it was observed that the antibacterial effects of the extracts were more prominent on Gram-positive bacteria compared to Gram-negative bacteria. These findings are parallel to the observations made by the other researchers in their studies in the literature (Basilio et al., 2003; Saadoun and Gharaibeh, 2003; Sahin, 2005). This might be explained by the difference in cell wall compositions between the two groups. The more peptidoglycan structure in the cell wall of Gram-positive bacteria makes these bacteria more sensitive to antibacterial agents, especially antibiotics (Yilmaz et al., 2008).

Also, various factors such as $\mathrm{pH}$, temperature, minerals, and culture media components affect secondary metabolite production. Some of the 11 isolates grown in Benett + Glucose medium had antimicrobial activity. On the other hand, they did not show any activity when they were grown in TSB medium. The difference in antimicrobial activity due to the factors mentioned above shows how important the medium is in this regard. The three isolates BA12, BA14, and BS29 were also found to have antimicrobial activity against $E$. coli and $C$. albicans when grown in modified Bennett's medium. Many studies have shown that the role of nutrients and the environment have very important effects on the amount and variety of secondary metabolite synthesis (Bills et al., 2008; VanderMolen et al., 2013). Different sources of carbon and nitrogen in the culture medium can increase or decrease the synthesis of a bioactive secondary metabolite through different ways, such as enzyme induction or inhibition. There are studies indicating that glucose is an effective and preferred carbon source for secondary metabolite synthesis by Streptomyces (Fguira et al., 2005). Also, Ouhdouch et al., (2001) stated that Bennett's medium was the best for antibiotic production among three media used in testing thirty-two strains of Streptomyces.

Table 2. Antimicrobial spectrum of the crude extracts of the isolates grown in Bennet's+Glucose and TSB media against several pathogens. The results represent the average mean zone diameters (in $\mathrm{mm}$ ) of three replicates using the disk diffusion method

\begin{tabular}{ccccccccccc}
\hline \multirow{2}{*}{ Isolates } & \multicolumn{9}{c}{ Bennett's+Glucose } & \multicolumn{5}{c}{ TSB } \\
\cline { 2 - 10 } & E. & S.aure & S.pyogen & P.aerugino & C.albica & E.co & S.aure & S.pyogen & P.aerugino & C.albica \\
\hline AR4 & - & - & 14 & - & - & - & - & - & - & - \\
AR6 & - & - & - & - & - & - & - & - & - & - \\
AR9 & - & 18 & 18 & - & - & - & - & - & - & - \\
AS28 & - & 10 & - & - & - & - & - & - & - & - \\
AS36 & - & - & - & - & - & - & - & - & - & - \\
BA12 & 8 & 12 & 16 & - & 5 & - & - & - & - & - \\
BA14 & 10 & 18 & 12 & - & 5 & - & - & - & - & - \\
BS29 & 12 & 18 & 20 & - & 7 & - & - & - & - & - \\
BS32 & - & 10 & - & - & - & - & - & - & - & - \\
CA12 & - & - & - & - & - & - & 5 & - & - & - \\
CS41 & - & 30 & 24 & - & - & - & 16 & 12 & - & - \\
\hline
\end{tabular}


Table 3. The results of the disk diffusion method for antibiotic susceptibility testing using standard antibiotics. The results represent the average mean zone diameters (in $\mathrm{mm}$ ) of three replicates

\begin{tabular}{lcccccc}
\hline $\begin{array}{c}\text { Tested } \\
\text { Organism }\end{array}$ & Imipenem & Netilmicin & Amoxicillin & Ofloxacin & Erythromycin & Amphotericin B \\
\hline S. aureus & 18 & 11 & 15 & 14 & 15 & - \\
S. pyogenes & 20 & 12 & 13 & 13 & 13 & - \\
C. albicans & - & - & - & - & - & - \\
E. coli & 15 & 13 & 11 & 14 & - & - \\
P. aeruginosa & 10 & 9 & - & 10 & - & - \\
\hline
\end{tabular}

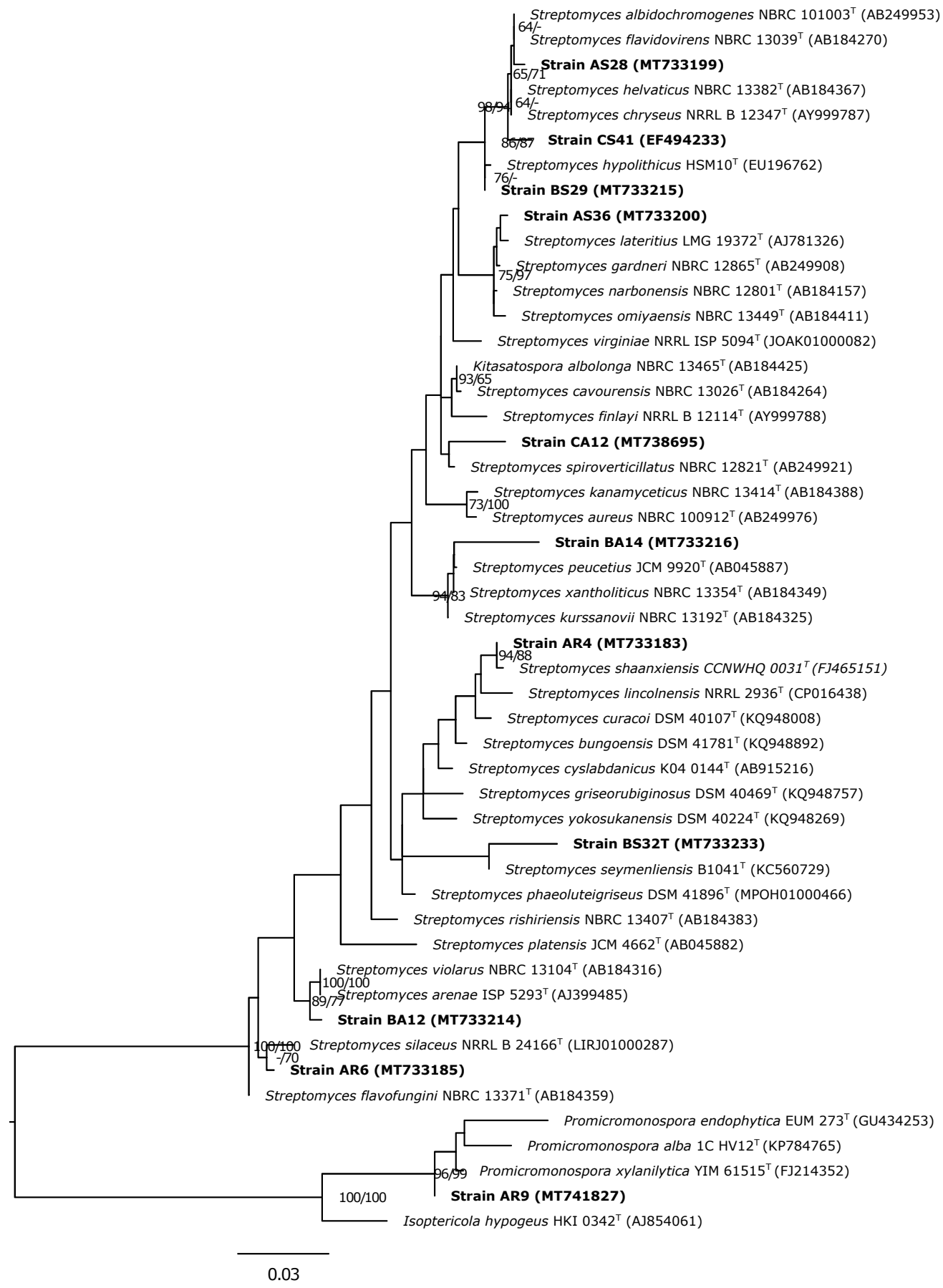

Figure 1. Phylogenetic tree based on the partial 16S rRNA gene analysis of the isolates.

(The phylogenetic tree was constructed by the maximum likelihood method and rooted by midpoint-rooting. The branches are scaled in terms of the expected number of nucleotide substitutions per site. The numbers at nodes indicate the bootstrap support values when larger than $60 \%$ from maximum likelihood (left) and maximum parsimony (right) bootstrapping. GenBank accession numbers are given in brackets.) 
Isolate AR9, our only isolate that does not belong to Streptomyces genus, was closely related to Promicromonospora xylanilytica $(99.50 \%)$. There is a limited number of studies in the literature about this bacterium. It was a non-spore-forming and xylan-degrading bacterium that was isolated as endophytic actinomycete by Qin et al., (2012). In a recent study, the researchers discovered three new products from the $P$. xylanilytica YIM 61515. Their structures and cytotoxicity against five human cancer cell lines were elucidated (Wang et al., 2018). Therefore, chemical investigation of this isolate might open new windows to the discovery of new secondary metabolites.

The previous studies demonstrated the antimicrobial activity of secondary metabolites extracted from different Streptomyces strains against pathogens microorganisms. Kalyani et al., (2019) stated that the ethyl acetate extracts of Streptomyces sp. NLKPB45 isolated from mangrove soil samples showed antimicrobial activity against Salmonella sp., S. aureus, E. coli, and B. subtilis (Kalyani et al., 2019). Moreover, the researcher observed that the crude extract from the Streptomyces sp. possessed antimicrobial activity against Bacillus cereus, Bacillus megaterium, Bacillus subtilis, Micrococcus luteus, S. aureus with the MIC values ranging from 5 to $50 \mu \mathrm{g} / \mathrm{mL}$ (Riahi et al., 2019).

The culture-dependent/independent approaches may contribute to the discovery of new bioactive secondary metabolites from different microbial sources. Bioactivity screening is the first and most important step in secondary metabolite studies to highlight novel metabolites. Recent secondary metabolite screening studies have revealed that novel antibiotics (teixobactin, lugdunin and formicamycins etc.) are being discovered with these strategies from environmental microbial strains (Ling et al., 2015).

\section{Conclusion}

In this study, existing isolates were found to be involved in phylum Actinobacteria as a result of molecular diagnostic studies. Eight of them showed remarkable antimicrobial activity. The study about the effect of two different media on the production of bioactive metabolites indicated that using modified Bennett's medium provided higher antimicrobial activity when compared to TSB. Secondary metabolites of microbial origin are very important precursor compounds in studies conducted to investigate new drugs. The discovery of new compounds by screening bioactive metabolites in the Streptomyces genus with high secondary metabolite production potential is a possible situation.

\section{Declarations}

This study was supported by TÜBİTAK-107T502.

\section{References}

Ay, H. (2020). Phylogeny of Plant Growth-Promoting Actinobacteria Isolated from Legume Nodules in Turkey. Yüzüncü Yll Üniversitesi Tarım Bilimleri Dergisi, 30, 611-619.

Basilio, A., Gonzales, I., Vicente, M. F., Gorrochategui, J., Cabello, A., Gonzales, A. \& Genilloud, O. (2003). Patterns of antimicrobial activities from soil actinomycetes isolated under different conditions of $\mathrm{pH}$ and salinity. Journal of Applied Microbiology, 95, 814-823.

Berdy, J. (2005). Bioactive microbial metabolites. The Journal of Antibiotics, 58, 1-26.

Bills, G. F., Platas, G., Fillola, A., Jiménez, M. R., Collado, J., Vicente, F., Serrano, J. M., Gonzalez, A., Zimmermann, J. B., Tormo, J. R. \& Peláez, F. (2008). Enhancement of antibiotic and secondary metabolite detection from filamentous fungi by growth on nutritional arrays. Journal of Applied Microbiology, 104, 1644-1658.

Bush, K., Courvalin, P., Dantas, G., Davies, J., Eisenstein, B., Huovinen, P., Jacoby, G. A., Kishony, R., Kreiswirth, B. R., Kutter, E., Lerner, S. A., Levy, S., Lewis, K., Lomovskaya, O., Miller, J. H., Mobashery, S., Piddock, L. J. V., Projan, S., Thomas, C. M., Thomasz, A., Tulkens, P. M., Walsh, T. R., Watson, J. D., Witkowski, J., Witte, W., Wright, G., Yeh, P. \& Zgurskaya, H. I. (2011). Tackling antibiotic resistance. Nature Reviews Microbiology, 9, 894-896.

Edgar, R. C. (2004). MUSCLE: multiple sequence alignment with high accuracy and high throughput. Nucleic Acids Research, 32,1792-1797. 
Fguira, L. F. B., Fotso, S., Ameur-Mehdi, R. B., Mellouli, L. \& Laatsch, H. (2005). Purification and structure elucidation of antifungal and antibacterial activities of newly isolated Streptomyces sp. strain US80. Research in Microbiology, 156, 341-347.

Johnson, J. S., Spakowicz, D. J., Hong, B. Y., Petersen, L. M., Demkowicz, P., Chen, L., Leopold, S. R., Hanson, B. M., Agresta, H. O., Gerstein, M., Sodergren, E. \& Weinstock, G. M. (2019). Evaluation of 16S rRNA gene sequencing for species and strain-level microbiome analysis. Nature Communications, 10:1-11.

Kalyani, B. S., Krishna, P. \& Sreenivasulu, K. (2019). Screening and identification of novel isolate Streptomyces sp., NLKPB45 from Nellore costal region for its biomedical applications. Saudi Journal of Biological Sciences, 26, 1655-1660.

Kämpfer, P. \& Labeda, D. (2006). International committee on systematics of prokaryotes; Subcommittee on the taxonomy of the Streptomycetaceae. International Journal of Systematic and Evolutionary Microbiology, 56, 495.

Kataoka, M., Ueda, K., Kudo, T., Seki, T. \& Yoshida, T. (1997). Application of the variable region in $16 \mathrm{~S}$ rDNA to create an index for rapid species identification in the genus Streptomyces. FEMS Microbiology Letters, 151, 249-255.

Kim, M., Oh, H. S., Park, S. C. \& Chun, J. (2014). Towards a taxonomic coherence between average nucleotide identity and 16S rRNA gene sequence similarity for species demarcation of prokaryotes. International Journal of Systematic and Evolutionary Microbiology, 64, 346-351.

Ling, L., Schneider, T., Peoples, A., Spoering, A. L., Engels, I., Conlon, B. P., Mueller, A., Schaberle, T. F., Hughes, D. E., Epstein, S., Jones, M., Lazarides, L., Steadman, V. A., Cohen, D. R., Felix, C. R., Fetterman, K. A., Millet, W. P., Nitti, A. G., Zullo, A. M., Chen, C. Lewis, K. (2015). A new antibiotic kills pathogens without detectable resistance. Nature, 517, 455-459.

Meier-Kolthoff, J. P., Auch, A. F., Klenk, H. P. \& Göker, M. (2013). Genome sequence-based species delimitation with confidence intervals and improved distance functions. BMC Bioinformatics, 14,60 .

NCCLS, National Committee for Clinical Lab. Standards (). (2002). Performance standards for antimicrobial disk susceptibility test: approved standard 6th ed, M2-A6.

Nett, M., Ikeda, H. \& Moore, B. S. (2009). Genomic basis for natural product biosynthetic diversity in the actinomycetes. Natural Product Reports, 26, 1362-1384.

Nouioui, I., Carro, L., García-López, M., Meier-Kolthoff, J. P., Woyke, T., Kyrpides, N. C., Pukall, R., Klenk, H. P., Goodfellow, M. \& Göker, M. (2018). Genome-based taxonomic classification of the phylum Actinobacteria. Frontiers in Microbiology, 9, 2007.

Ouhdouch, Y., Barakate, M. \& Finance, C. (2001). Actinomycetes of Moroccan habitats: Isolation and screening for antifungal activities. The European Journal of Soil Biology, 37, 69-74.

Qin, S., Jiang, J. H., Klenk, H. P., Zhu, W. Y., Zhao, G. Z., Zhao, L. X., Tang, S. K., Xu, L. H. \& Li, W. J. (2012). Promicromonospora xylanilytica sp. nov., an endophytic actinomycete isolated from surface-sterilized leaves of the medicinal plant Maytenus austroyunnanensis. International Journal of Systematic and Evolutionary Microbiology, 62, 84-89.

Riahi, K., Hosni, K., Raies, A. \& Oliveira, R. (2019). Unique secondary metabolites of a Streptomyces strain isolated from extreme salty wetland show antioxidant and antibacterial activities. Journal of Applied Microbiology, 127, 1727-1740.

Saadoun, I. \& Gharaibeh, R. (2003). The Streptomyces flora of Badia region of Jordan and its potential as a source of antibiotics active against antibiotic-resistant bacteria. Journal of Arid Environments, 53, 365-371.

Sahin, N. (2005). Antimicrobial activity of Streptomyces species against mushroom blotch disease pathogen. Journal of Basic Microbiology, 45, 64-71.

Schein, C. H. (2020). Repurposing approved drugs on the pathway to novel therapies. Medicinal Research Reviews, 40, 586-605.

Stackebrandt, E. \& Goebel, B. M. (1994). Taxonomic note: A place for DNA-DNA reassociation and 16S rRNA sequence analysis in the present species definition in bacteriology. The International Journal of Systematic and Evolutionary Microbiology, 44, 846-849.

Stackebrandt, E. \& Ebers, J. (2006). Taxonomic parameters revisited: Tarnished gold standards. Microbiology Today, 33, 152-155. 
Stamatakis, A. (2014). RAxML version 8: A tool for phylogenetic analysis and post-analysis of large phylogenies. Bioinformatics, 30, 1312-1313.

Tindall, B. J., Rosselló-Móra, R., Busse, H. J., Ludwig, W. \& Kämpfer, P. (2010). Notes on the characterization of prokaryote strains for taxonomic purposes. The International Journal of Systematic and Evolutionary Microbiology, 60, 249-266.

VanderMolen, K. M., Raja, H. A., El-Elimat, T. \& Oberlies, N. H. (2013). Evaluation of culture media for the production of secondary metabolites in a natural products screening program. $A M B$ Express, 3, 1-7.

Wang, Z. X., Qin, S., Xu, L. H., Chen, H. P., Sun, H., Huang, R., Li, Z. H., Feng, T. \& Liu, J. K. (2018). Xylanilyticolides A-C, three new compounds from cultures of the actinomycete Promicromonospora xylanilytica YIM 61515. Natural Products and Bioprospecting, 8, 91-95.

WHO. (2014). Antimicrobial Resistance: Global Report on Surveillance. Geneva, Switzerland.

Yilmaz, E. I., Yavuz, M. \& Kizil, M. (2008). Molecular characterization of rhizospheric soil streptomycetes isolated from indigenous Turkish plants and their antimicrobial activity. World Journal of Microbiology and Biotechnology, 24, 1461-1470. 